\title{
LOS CINCO GREMIOS MAYORES DE MADRID Y EL COMERCIO COLONIAL EN EL SIGLO XVII
}

\author{
POR \\ JORGE PINTO RODRIGUEZ \\ Universidad de la Frontera Temuco-Chile
}

La participación de la Compañía General de los Cinco Gremios Mayores de Madrid en el comercio colonial durante el siglo XVII permite observar una serie de problemas que afectaron las relaciones entre la metrópoli y las colonias, en los momentos en que se aceleraron los cambios que desembocarán en la Independencia.

En este artículo me referiré a uno de ellos. Trataré de examinar los esfuerzos que se hicieron en España por ampliar y agilizar el mercado americano a la naciente industria española, dejando en evidencia la intervención de la Corona en favor de los nuevos grupos económicos surgidos en la Península, en desmedro de los que se habían constituido en América.

El planteamiento central que aquí se expondrá gira en torno a la idea de que existió una estrecha relación entre la evolución de la economía española y las reformas que se aplicaron en América durante el siglo XVIII, cuya finalidad habría obedecido, según lo han probado recientes investigaciones, a la necesidad

SigLAS UTILIZADAS:

AGI: Archivo General de Indias, Sevilla.

AGN: Archivo General de la Nación, Lima.

MB: Museo Británico, Londres.

La consulta documental y bibliográfica para la elaboración de este artículo se hizo gracias al apoyo del Servicio Mundial de Universidades (WUS), de la Comisión Nacional de Investigación Científica y Tecnológica de Chile (CONICYT) y del Consejo Británico, organismos que financieron estadías en Sevilla, Lima y Londres, respectivamente. Un agradecimiento especial debo al profesor John Lynch por sus interesantes orientaciones y al Instituto de Estudios Latinoamericanos de la Universidad de Londres por haberme acogido como Investigador Asociado entre mayo y julio dé 1990, oportunidad en la cual redacté la versión definitiva de este artículo. En Chile, María T. Cobos ha contribuido también a corregir numerosas deficiencias. 
de liberalizar el mercado americano a diferentes puertos españoles y al deseo de penetrar las articulaciones económicas que se habían tejido en el interior del mundo colonial, con el propósito de abrir un espacio a la producción manufacturera de la naciente industria española, que requería con urgencia un mercado que desbordara al que se había formado en la península.

De este modo, los grupos de poder vinculados a ella empezaron a presionar a las autoridades del gobierno central para que adoptaran medidas que favorecieran su desarrollo, obligando a la Corona a extender primero el comercio colonial a diversos puertos españoles y a aprobar más tarde el decreto del libre comercio en 1778 (1). Se rompía así, el eje Madrid-Sevilla-Cádiz y adquiría forma lo que John Lynch ha llamado «el nuevo imperialismo" (2).

Sin embargo, tengo la impresión que las dos medidas anteriores no fueron suficientes para resolver el problema. Al ampliarse el comercio entre España y América, los comerciantes que llegaron al Nuevo Mundo constataron una realidad no prevista.

En torno a los polos mineros que conectaban las colonias con la metrópoli se habian constituido espacios que proporcionaban el abastecimiento que esos polos requerían. Junto a ello, ciertos funcionarios que favorecían el comercio interior, facilitaban la extracción de excedentes producidos por las comunidades locales y colocaban entre ellas mercaderías que obtenían de grandes

(1) Sobre este punto se puede citar una extensa bibliografía. Los trabajos que más contribuyeron en la elaboración de este artículo son los siguientes: Gonzalo AnÉs, El Antiguo Regimen: los Borbones, (Madrid, 1975); Marcelo BITAR, Economistas españoles del siglo XVIII, Madrid, 1968; Emiliano FERNÁNDEZ DE PINEDO et al... Centralismo, Ilustración y Agonía del Antiguo Regimen (1715-1833). Barcelona, 1981; Josep FonTANA, "Comercio colonial y crecimiento económico: revisiones e hipótesis", en La Economia Española al final del Antiguo regimen. III. Comercio y Colonias, Madrid, 1982; Antonio GarcíA-BAQUERO, "Comercio y producción industrial en Cataluña a fines del siglo XVIII", en J. NADAL y G. TORTELLÁ (eds.), Agricultura, comercio colonial y crecimiento económico en la España Contemporánea, Barcelona, 1974; Antonio García-Baquero, Cádiz y el Atlántico, Sevilla, 1976; Miguel IZARD, "Comercio libre, guerras coloniales y mercado americano", en J. Nadal y G. TORTEllá (eds.), obra citada; John LynCH, Bourbon Spain, 17001808, Oxford, 1980; Carlos MarTínez Shaw, "Los orígenes de la industria algodonera catalana y el comercio colonial", en J. NADAL y G. TORTELLÁ (eds.), obra citada; Pedro SchWARTz, "Cuatro economistas ante el fenómeno colonial español: Campomanes, Adam Smith, Flores Estrada y Bentham", en Historia Económica y Pensamiento Social. Edición et Introducción de Gonzalo ANÉs et al., Madrid, 1983; Jaime Vicens VIVES, Coyuntura económica reformismo burgués, Barcelona, 1969; Pierre VILAR, Crecimiento y Desarrollo. Barcelona, 1976; Pierre VILAR et al., La industrialización europea. Estudios y tipos Barcelona, 1981, y Geoffrey J. WALKER, Politica española y comercio español, 1700-1789, Barcelona, 1979.

(2) John LyNCH, The Spanish American Revolutions, 1808-1826, Segunda edición, W. W. Norton and Company. New York, 1896, pág. 2. 
comerciantes, que los ayudaban a conseguir esos cargos con el compromiso de favorecer más tarde sus negocios particulares. Eran los casos de los alcaldes mayores en México y de los corregidores en el Perú.

El papel de los polos mineros y el rol que jugaron los funcionarios que acabo de mencionar, permitieron la constitución de interesantes articulaciones económicas que se fueron desarrollando lentamente hasta madurar en el siglo XVIII (3).

La intencion de abrir el mercado americano obligaba, pues, a romper o penetrar aquellas articulaciones y uno de los primeros caminos que se intentó en España para lograr este propósito, creo que fueron las compañías comerciales que se interesaron en el tráfico ultramarino. Esto explica el apøyo que encontraron tanto en España como en América de parte de las autoridades que comprendieron el verdadero alcance de las reformas borbónicas.

Esta es la primera cuestión que queda en evidencia al examinar la actuación de la Compañía General de los Cinco Gremios Mayores de Madrid en el comercio americano, sobre todo si se tiene en cuenta el caso peruano, cuyo análisis privilegiaré debido a las fuentes que manejo.

Hay, sin embargo, otro asunto sobre el cual también conviene anticipar algunos planteamientos. Sin poner en duda que la reforma de las Intendencias obedeció al propósito de superar viejas estructuras administrativas que restaban dinamismo al Imperio, tengo la impresión de que en un momento determinado ésta se orientó en América más que nada a romper las barreras que interponian los alcaldes mayores y los corregidores al libre flujo de los productos que empezaban a llegar desde España.

Por este motivo, la reforma de las Intendencias constituye, en mi opinión, el esfuerzo más serio que se hizo para adecuar el mercado americano a la naciente industria peninsular. Una vez aplicada, de nuevo se volvió a mirar a las compañías comerciales, esta vez como una alternativa para reemplazar a los funcionarios que habían dinamizado el tráfico y la preducción locales. Esto permite comprender la fuerte resistencia que encontraron en los grupos económicos que habían florecido en virtud de la tan escasa intervención de España en la economía colonial y el ma-

(3) Respecto de este punto también se puede citar una extensa bibliografía. Los trabajos más relevantes creo que son los de Carlos SEMPaT Assadourian, El sistema de la economia colonial, Lima, 1982; Carlos CONTRERAs, La ciudad del Mercurio. Huancavelica. 1570-1700, Lima, 1982; y Juan Carlos Garavaglia, Mercado interno y economía colonial México, 1983. 
nifiesto apoyo que encontraron en las autoridades dispuestas a poner fin a esa situación. En el caso de los Cinco Gremios, otra vez será el ejemplo peruano el que dejará en evidencia lo que acabo de señalar, mostrando, además, que detrás de la polémica se enfrentaban dos posiciones: una que buscaba el desarrollo de España sin preocuparse demasiado de las colonias y otra que, sin perder de vista los intereses peninsulares, aspiraba a un desarrollo más integral del Imperio.

\section{LOS CINCO GREMIOS Y SUS ACTIVIDADES ECONÓMICAS}

Aunque algunos de los gremios que más tarde constituirán la Compañía General y de Comercio de los Cinco Gremios Mayores de Madrid existían en el siglo XIX, es más seguro remontar su origen al XVI, época en la cual figuraban actuando separadamente (4). En el seiscientos se les podía identificar con toda claridad. El primero estaba formado por los mercaderes de seda, cuyas operaciones se relacionaban con los terciopelos, brocados, damascos, tejidos, tafetanes y otros artículos vinculados a la sedería. El segundo lo constituían los mercaderes de joyas, encargados de la venta de alhajas y objetos de uso femenino, tales como medias de seda, guantes, bolsos, carteras, perfumes y todo cuanto satisfacía las exigencias de la moda. El tercero estaba formado por los mercaderes de lencería, que controlaban el comercio de lienzos, manteles, servilletas, géneros de Holanda y telas de París. A su lado figuraban los mercaderes de mercería, especialistas en tafetanes, botones de seda, hilos de colores, sedas, pañuelos y artículos de mercería, que con el tiempo absorbieron enteramente su atención, hasta convertirse en el gremio de esa especialidad. Por último, habría que mencionar a los mercaderes de paños, dedicados a la venta de paños de Segovia, Holanda, Francia y Flandes, que introducían a la península por medio de una cadena de agentes distribuidos en varios países de Europa.

Sus primeros contactos se iniciaron hacia 1667, a propósito

(4) Miguel Capella y Antonio Matilla Tascón, Los Cinco Gremios Mayores de Madrid. Estudio critico-histórico. Madrid, 1957. La mayoría de los datos que entrego en las páginas siguientes provienen de este estudio. Más información en Eduardo ARCILA, El siglo ilustrado en América. Reformas económicas del siglo XVIII en Nueva España, Buenos Aires, 1955, págs. 22-38; Gonzalo ANÉs, Las crisis agrarias en la España Moderna, Madrid, 1974, págs. 351-361; y Pere Molas, La burguesía mercantil en la España del Antiguo Regimen, Madrid, 1985, págs. 81. 83. 
de una querella criminal que se ventiló entre los mercaderes de seda y los comerciantes de lonja. En esa oportunidad, todos hicieron causa común, excepto los de paños, hasta entonces poco dispuestos a unirse a los demás. Sin embargo, dos años más tarde actuaban en completa armonía, a lo que contribuyó después el hecho de que en 1684 pasaran todos a depender de la Junta de Comercio. Sus primeras ordenanzas se aprobaron en 1686, constituyendo definitivamente la Asociación de los Cinco Gremios Mayores de Madrid, en 1731, cuando se separaron de los gremios menores. El programa que aprobaron ese año permite conocer la dimensión de la institución que se estaba fundando.

En el plano del comercio, los Cinco Gremios se propusieron defenderlo como una alternativa de desarrollo, justo en el momento en que éste iniciaba un ciclo expansivo en Europa y América. Tal defensa se orientó, también, a combatir la competencia de otros gremios, actitud que no podían postergar, porque el consumo suntuario de la nobleza cortesana concentrada en Madrid, favorecía el auge del artesanado asociado en gremios (5). En el terreno de sus relaciones con el fisco se esforzarían por convertirse en los principales tributarios del Estado y en los únicos proveedores de recursos para la Corte. Para ello se comprometían a recaudar las rentas reales de la Villa de Madrid, a arrendar otras y a negociar con los vales reales. En el campo de la industria sus aspiraciones no fueron menores: tratarían de conseguir diversas fábricas, encargándose no sólo la producción, sino también a la comercialización de sus productos. Como institución financiera se encargarían de recibir dinero en depósito y otorgar créditos a particulares y al propio gobierno. Finalmente, entre sus actividades varias contemplaban el flete de naves y los seguros marítimos. Es decir, una amplia gama de gestiones económicas, propias de una época, marcada en España por el signo de la recuperación económica, después de la contracción del siglo XVII. Naturalmente, la Compañía contaba con el apoyo de un estado que necesitaba resolver sus problemas financieros y fomentar la producción y el comercio del país. Por esta razón, la Junta de Población, Agricultura y Comercio, creada en la Península para estimular la economía, no sólo aprobó su fundación, sino aplaudió sus ingresos.

En la formación de las compañías comerciales que contaron con la participación de los Cinco Gremios se pueden distinguir dos etapas. La primera constituyó una fase preliminar en la que

(5) ANÉs, El Antiguo Regimen, [1], pág. 260. 
cada gremio integraba compañías particulares con recursos de sus propios asociados. La segunda los unió en una sola entidad, en un movimiento de clara expansión, que se inicia en la tercera década del XVIII, y que tuvo como base el asiento de las rentas reales, cuyas utilidades generó los recursos para incursionar en un comercio más complejo.

La primera compañía que formaron los Gremios nació, justamente, en 1734 con ocasión de habérseles concedido el arriendo de las rentas reales de Madrid. Sin embargo, más importante fue la que fundaron en 1752, constituida por aportes iguales, con un capital de un millón de reales. La Compañía estaba autorizada para intervenir en todo el comercio que estuviera a su alcance, tanto en Europa como en América, encargándose de su gobierno una comisión de cinco apoderados, uno por cada gremio. Muy pronto esta Compañía entró en contacto con otra que habían formado en Cádiz los hermanos Ustáriz, quienes disponían de una adecuada infrestructura y experiencia para incursionar en el comercio colonial (6). Esta asociación permitió a los Cinco Gremios tener casa en el puerto gaditano, cuyo manejo corrió por cuenta de los Ustáriz, con el compromiso de éstos de mantener correspondencia permanente con la casa central de Madrid. El capital inicial fue de 15 millones de reales, diez aportados por los Gremios y cinco por sus socios.

En 1763 se independizaron de los Ustáriz y, ese mismo año, formaron la Compañía General y el Comercio de los Cinco Gremios Mayores de Madrid, bajo la advocación de Nuestra Señora del Rosario y San Francisco de Asís. El capital inicial fue de 15 millones de reales, aportados esta vez exclusivamente por ellos. La Compañía se proponía comerciar en Europa, América y en cualquier lugar que se estimara conveniente. Para la dirección de la casa de Cádiz, una de las más importantes, se nombrarían dos directores, elegidos entre los socios de la misma institución. Además del comercio, la Compañía estaba facultada para intervenir en otros negocios: seguros, rentas vitalicias, manejo de fábricas reales, etc. Su dirección quedó a cargo de una Junta de Gobierno y Dirección constituida para este único fin. Veinte años más tarde su capital se había duplicado. Este fue el punto de partida de la expansión definitiva de la Compañía de los Cinco Gremios.

Para tener una idea del volumen que fue adquiriendo, es interesante consignar el caudal que declaró hacia 1775. En total,

(6) Arcila, [4], pág. 23. 
el número de sus asociados se estimó en 374 personas y sus fortunas, de acuerdo al cuadro $\mathrm{n}^{\mathrm{0}}$ 1, en 209 millones de reales. Vale decir, un capital que superaba largamente los 15 millones iniciales de 1763.

CUADRo № 1. NUMERO DE ASOCIADOS Y CAUDALES DE LOS CINCO GREMIOS EN 1775

\begin{tabular}{lcc}
\hline GREMIOS & ASOCIADOS & $\begin{array}{c}\text { CAUDALES } \\
\text { (en millones de reales) }\end{array}$ \\
\hline Seda & 35 & 28 \\
Paños & 56 & 25 \\
Joyería & 61 & 26 \\
Especiería & 129 & 90 \\
Lienzos & 93 & 40 \\
TOTALES & 374 & 209 \\
\hline
\end{tabular}

Fuente: Capilla y Matilla, 1957, pág. 125.

La pujanza de los Gremios había empezado en 1734, después de obtener el arriendo de las rentas reales de Madrid por un período de nueve años. A partir de ese momento, no volvieron a salir de sus manos hasta 1816, permitiéndoles todo tipo de manejo con la Hacienda Real, cuyos recursos empezaron a depender de los anticipos que ellos le otorgaban. Así pues, el gobierno se vio obligado no sólo a aceptar sus propuestas de asientos sucesivos durante más de ochenta años, sino a concederles, las rentas del excusado, los maestrazgos, cuarteles y utensilios, el monopolio del comercio con Marruecos, privilegios para sus fábricas y la provisión del ejército, esto último en 1760. Cuando en 1786 el Banco Nacional de San Carlos los reemplazó en esta última función, denunció a los Cinco Gremios por vender mercaderías con un recargo del 20 por ciento, sin considerar las ganancias adicionales que obtenían debido a que parte de la renta del excusado les llegaba en granos que aprovechaban para surtir al ejército. A pesar de las denuncias, los Gremios recuperaron la provisión en 1791, porque eran los únicos capaces de reunir viveres en grandes cantidades y transportarlos con rapidez.

Gracias a sus contactos con el Estado lograron hacerse cargo 
de diversas fábricas reales en distintos puntos de la Península. De este modo colocaron bajo su control las fábricas de tejidos de Cuenca, la de hilados y seda de Murcia y la de sombreros de San Fernando, disponiendo con ello de una producción regular que comercializaban a través de la Compañía de Comercio formada en 1763.

Como prestamistas del gobierno jugaron también un importante papel. Se iniciaron en esto hacia 1769, cuando se les entregó el manejo del Fondo Vitalicio creado ese mismo año. Al fundarse el Banco de San Carlos en 1782, perdieron la función de prestamistas casi exclusivos del Estado; sin embargo, las crecientes necesidades de éste le obligaron a golpear de nuevo sus puertas. Lo mismo aconteció con los vales reales emitidos por la Hacienda Real en 1780, con el objeto de conseguir crédito de particulares. La idea había sido concebida por el francés Francisco Cabarrús, con el propósito de desplazar a los Gremios de su condición de banqueros del gobierno. La continua emisión de vales y la desconfianza que empezaron a despertar en el público, obligaron a las autoridades a apelar otra vez a los Gremios para controlar su liquidez (7). Para entonces eran la garantía más sólida, aunque se aprovecharan de la coyuntura en su propio beneficio.

Aparte de los créditos otorgados al Estado, la caja de los Cinco Gremios fue durante la segunda mitad del siglo XVIII una especie de banco público al que acudían particulares a depositar dineros a un intéres del 2,5 ó $3 \%$ y a solicitar empréstitos a un interés mayor. En este campo, entre sus mejores clientes figuraban los jesuitas.

La envergadura de los negocios que manejaban instó a los Gremios a poner factorías en las principales ciudades europeas. Tuvieron una en Londres, otra en Hamburgo y una tercera en París. En Amsterdam operaron con Courtien, Echeñique, Sánchez y Cía., casa española que mantenía allí una importante representación. Desde Europa extendieron sus actividades al mundo colonial. Se ha dicho que al comienzo se valieron de la casa de los Ustáriz de Cádiz, de la cual se independizaron en 1763. A fines del XVIII mantenían factorías en las principales ciudades americanas, desarrollando un activo comercio a través del Atlántico.

(7) Este punto ha sido tratado con cierta extensión por Gonzalo ANÉs en su estudio "Sociedad y Economía", publicada en Actas del Congreso Internacional sobre "Carlos III" y la Ilustración. Tomo II. Economía y Sociedad. Madrid, 1989, págs. 111-138. 
Más allá de éste, incursionaron incluso en el tráfico a Manila, asociándose para ello a la Compañía de Filipinas.

En síntesis, al promediar la segunda mitad del siglo XVIII, la Compañía General de los Cinco Gremios Mayores de Madrid era una pujante empresa que intervenía en múltiples actividades económicas (8).

\section{LAS PRIMERAS ACTIVIDADES EN AMÉRICA}

Aunque oficialmente los Cinco Gremios formaron compañía con los Ustáriz en 1752 para ocuparse del comercio colonial, ya antes habían mostrado interés por este tráfico. Hay constancia de que en 1748 embarcaron en La Coruña 14 cajones de mercaderías con destino a Cartagena, telas en su mayor parte. Ese mismo año enviaron papel y loza de vidrio a Veracruz y Lima, mercaderías que fueron embarcadas en el puerto del Ferrol (9).

Ninguna de estas operaciones tuvo éxito. Una de las naves que se dirigía a Veracruz fue desviada por unos temporales a Puerto Rico, desde donde pasó a La Habana, para llegar con mucho retraso a su destino. En la travesía se rompió casi un tercio de la loza, originando pérdidas que los comisionados trataron de salvar solicitando una rebaja en los impuestos de internación. El envío hecho al Perú no corrió mejor suerte. La mayor

(8) No cabe duda de que en el marco de la economía madrileña y, aún española, los Cinco Gremios constituían en el siglo XVIII un ejemplo de pujanza y poderío. Sin embargo, no es tan claro que quede la misma impresión si se les analiza en el plano de la economía europea. En este sentido se podría afirmar que no superaron los límites que les imponía su condición de representantes tipicos de la burguesía mercantil de un país cuyos progresos en el Antiguo Regimen fueron menores a los de sus vecinos del norte, especialmente Inglaterra y Alemania. John Lynch participa de la idea de que la fuerza que manifiestan en España, se diluye en el contexto europeo y que esto tiene, además, alguna relación con las características de su principal centro de operaciones. Madrid, que no pasaba de ser una ciudad parasitaria de una economía castellana sin mucho dinamismo. Lamentablemente no he podido consultar el trabajo de David RINGROSE, Transportation and economic stagnation in Spain, 1750-1850. Durham, N. C.: 1970, en el cual el profesor Lynch me señaló existir excelente información. En desmedro de esta deficiencia, el libro de Pere MoLAS, [4], aporta interesantes comentarios para dimensionar adecuadamente el peso de las Cinco Gremios en la economía y sociedad del siglo XVIII. De acuerdo a éste, la Compañía se vio seriamente limitada por sus rasgos conservadores y tradicionales, propios de una época en la que aun no aparecía la burguesía industrial.

(9) Expediente sobre envíos hechos en los navíos San Nicolás, Castilla y Eurøpa, 1748. AGI, Indiferente General, leg. 1622. 
parte de la mercadería quedó sin venderse, por ser del tipo que no se consumía en el virreinato.

Estos fracasos parecen haber movido a los Gremios a tomar contacto con los Ustáriz, cuya experiencia en el comercio colonial era vastamente probada. En 1750, uno de éstos, don Juan Agustín Ustáriz, figura como su apoderado en Cádiz, con el encargo de recibir las mercaderías que les llegaban en retorno de las costas americanas (10). De éstas, la que primero acaparó su atención fue el cacao de Guayaquil y Caracas. A pesar del control que ejercía sobre éste producto la Compañía Guizpuzcoana, sólo en los primeros seis meses de 1750 , Ustáriz recibió a nombre de sus representados 5.939 fanegas de Caracas y 4.593 de Guayaquil, cuya venta se dispuso a precios que oscilaban entre 29 y 34 pesos la fanega. Al año siguiente recibieron una cantidad superior, siempre al alero de los Ustáriz. Este año hicieron también algunos envíos de mercaderías a Veracruz y Buenos Aires, pero, el mayor volumen de sus actividades giró en torno al cacao (11).

La preferencia que brindaron al cacao -y después al azúcar-, se explica por la fuerte vinculación que tenían con Madrid, uno de los principales centros de consumo de esos productos. Así pues, no cabe duda que sus primeras actividades se orientaron a satisfacer la demanda de sus clientes más cercanos, aquellos que como ellos residían en la capital del Imperio (12).

Las perspectivas que ofrecía el tráfico con América influyó en la formación de la compañía con los Ustáriz que formalizaron en 1752. A partir de ese año, sus actividades se multiplicaron. Esta época coincide, además, con el momento en que empiezan a hacerse cargo de algunas fábricas que la Corona tenía en España, situación que favoreció el comercio que hacían con las colonias, pues empezaron a recibir un trato preferencial del gobierno. Así, por ejemplo, a partir de 1755 se les concedió un navío en la flota anual con la única obligación de

recibir y pagar por su justo valor todos los géneros que se

(10) Razón del cacao de Caracas y Guayaquil entregado a Juan Agustín de Ustáriz, apoderado de los Cinco Gremios. Cádiz, 10.11.1750, AGI, Indiferente General, leg. 1622.

(11) Las mercaderías embarcadas en 1751 eran, en su mayoría ropas de las fábricas de San Fernando y Guadalajara. Véase Expedientes sobre envíos hechos en los navíos Lidia, San Miguel, Animas y San Raimundo. Cádiz, 9.2.1751 al 21.9.1751. AGI, Indiferente General, leg. 1622.

(12) José Miguel Medrano y Carlos Malamud, "Las actividades de los Cinco Gremios Mayores en el Perú. Apuntes preliminares". En Revista de Indias, vol. XLVIII, núms. 182-183. Madrid, enero-agosto 1988, págs. 421-433. 
hallaban existentes de la Real Hacienda procedidos de sus reales fábricas de tejidos de oro, plata y seda y de tomar cada año, desde el de 1756 en adelante, hasta la cantidad de 800 a 900 mil reales de los propios tejidos en todas las especies (13).

En 1757 se les hizo otra concesión similar, esta vez con la obligación de hacerse cargo, y por diez años, de las reales fábricas de San Fernando, Guadalajara y Brihuega. Para ello habían preparado un navío de registro de 170 toneladas, que esperaban movilizar entre la Península y Honduras, para abastecer, según ellos, una región que era la mayor consumidora de esas ropas (14). Sin embargo, el mejor mercado para esas fábricas seguía siendo Madrid (15). El interés por ellas demuestra el escaso deseo que tenían de abandonar su tradicional centro de operaciones.

La forma como manejaron los primeros negocios permite conocer las razones de su éxito y al mismo tiempo, las causas que provocarían más tarde su ruina. $\mathrm{El}$ regateo de los precios, la especulación, el aprovechamiento de las franquicias que les otorgaba el gobierno y la ampliación de sus actividades a partir de la operación inicial, constituían el pilar de las ganancias: en tanto que los créditos concedidos a comerciantes locales, sin calcular demasiado los riesgos, empezaron a acumular deudas que jamás se recuperaron, abriendo las puertas al fracaso. Vale la pena ilustrar ambas situaciones con algunos ejemplos.

Los Gremios habían venido manifestando interés por el envío de ropas a Honduras desde 1755, año en que consiguieron la autorización para cargar el registro de 170 toneladas que prepararon casi de inmediato. En 1756 se les concedió otra autorización por 100 toneladas. Al interés de los Gremios, acrecentado por la posibilidad de controlar la extracción del palo de campeche, producto fundamental para las tinturas que se usaban en las manufacturas textiles, se sumaba el de la propia Corona, decidida a recuperar el mercado caribeño, dominado hasta entonces por

(13) Cuncesión hecha por el monarca en diciembre de 1758. AGI, Indiferente General, leg. 1622.

(14) Se trataba del navio San Rosendo. Expedientes sobre el comercio en Honduras, 1755-1757. AGI, Indiferente General, leg. 1622.

(15) Angel García Sanz, "Industria textil tradicional y las reformas de la Ilustración: las transformaciones de la pañería segoviana durante el reinado de Carlos III". En Actas del Congreso Internacional sobre "Carlos III y la Ilustración", págs. 363-387. La referencia al punto señalado en pág. 374. 
Inglaterra (16). Así pues, el apoyo de las autoridades no se hizo esperar. Sin embargo, de común acuerdo con los Ustáriz, retardaban los envíos hasta que el mercado estuviera en las mejores condiciones para ellos. Esta irregularidad fue denunciada por el ministro Avaria en 1757, quien les amenazó con otorgar concesiones a otros interesados, en vista de la confianza que manifestaban en que nadie más obtendría ese privilegio, tomándose la libertad, decía el ministro, de esperar a «que escasee en aquel reino de Guatemala de todo" (17).

Los Gremios justificaron su actitud con diversos argumentos: pero, en el fondo, lo que pretendían era que se les autorizara cargar una nave de mayor tonelaje, reservando el sobrante para otras mercaderías que les interesaba llevar a las colonias. Conseguido esto empezaba en América la segunda parte del peculado. Aduciendo incapacidad del mercado para consumir lo conducido, presionaban a las autoridades para que les permitieran trasladar los productos a otros puertos, especialmente a los mexicanos, sin importarles demasiado el interés de la Corona por afirmar su soberanía en esos dominios que, para el caso, estaban prácticamente en manos de los ingleses (18). Quejándose, después, de pérdidas y atrasos en las ventas, solicitaban rebajas tributarias, que muchas veces la Real Hacienda se veía forzada a conceder por los compromisos contraídos con ellos. Finalmente, se aprovechaban del retorno de las naves para conducir productos de segura venta en los mercados europeos, aunque con ello contravinieran las disposiciones legales.

Así ocurría, por ejemplo con el azúcar cubano, cuya compra en la Habana no era bien vista por la Corona, por el riesgo de que los dineros cancelados por el producto pasaran a contraban-

(16) Guido DonOso, "La penetración comercial inglesa en el caribe español a mediados del siglo XVIII". En Revista Historia, Universidad de Concepción, año II, vol. II, núm. II (Segunda Epoca) Concepción, 1977, págs. 19-41.

(17) Carta del ministro Avaria. Madrid, 25.1.1757, AGI, Indiferente General, leg. 1622.

(18). La idea de que los gremios tenían hacia esos años mayor interés en el comercio con México, se conforma por los reparos que puso su representante en Guatemala, en 1758 , a la proposición de los comerciantes guatemaltecos de embarcar añil por La Habana, en vez de Veracruz. Aunque el rey accedió a la petición de los comerciantes de Guatemala, se puede apreciar el deseo de los Gremios de mantener la ruta de Veracruz, debido también a la posibilidad que tenían allí de embarcar el cacao venezolano que llegaba a su feria. Véase, Manuel RUBIO SÁNCHEZ, "Comercio terrestre en la Audiencia de Guatemala con el virreinato de Nueva España" (Segunda Parte). En Anales de la Sociedad de Gøegrafía e Historia de Guatemala, tomo XLIV, enero 1971, págs. 297-327; y Eduardo ARCILA, Comercio entre Venezuela y México en los siglos XVII y XVIII, México, 1950. 
distas extranjeros. Tomás Ortiz de Landázuri, de la Contratación de Veracruz precisaba:

Si los Gremios quisieran negociar azúcares de buena fe, deberán ajustarlos a pagar en Cádiz como lo hacen aquellos comerciantes celosos o dueños de navíos acomodados, que se contentan con el moderado lucro de esta segunda negociación, sin fraude de los derechos reales y los hacendados y vecinos de La Habana, que se proveen por el comercio lícito (19).

Con el cacao procedían de manera diferente. Arovechando el fuerte poder de compra que disponían en Cádiz obtenían, a través de regateo, precios muy inferiores a los que habitualmente conseguían otros comerciantes. En cambio, las ventas las hacían a precios más altos porque podían esperar el momento más oportuno para las operaciones de entrega (20). Aunque en esto los comisionados de los Gremios fueron verdaderos maestros, no resultaron tanto en la forma como manejaron la ventas en América. La enorme cantidad de mercaderías que transportaban, les obligaba a dejarlas a crédito. Quedaban así, a merced de mercaderes no siempre dispuestos a cumplir sus compromisos. No es posible cuantificar el monto de los créditos al término de la compañía con los Ustáriz, pero, todavía en 1770 sus allegados en la Corte intentaban obtener una recomendación del monarca para que el virrey de México apurara el cobro de las deudas contraídas en la época en que habían operado con la casa gaditana. A pesar de haber obtenido la recomendación, éste fue un problema que los Gremios jamás resolvieron exitosamente (21).

\section{LA AMPLIACIÓN DE SUS NEGOCIOS Y LA REACCIÓN DE LOS COMERCIANTES AMERICANOS. EL CASO PERUANO}

La disolución de la compañía que habían formado con los Ustáriz en 1752 dio paso, en 1752, a la creación de la Compañía General y de Comercio de los Cinco Gremios Mayores de Madrid.

(19) Informe de Tomás Ortiz Landázuri. Veracruz, 14.1.1769, AGI, Indiferente General, leg. 1622.

(20) Expedientes relativos al cacao de Caracas y Guayaquil entregado a don Agustín de Ustáriz, 1750-1751. AGI, Indiferente General, leg. 1622.

(21) Solicịtud del Gremio de Paños por ventas hechas de las reales fábricas de San Fernando, Guadalajara y Brihuega, 1770, AGI, Indif erente General, leg. 1622. En principio el Consejo de Indias denegó esta petición, pero luego la apoyó. 
A partir de ese momento, todos los negocios que emprendieron en América quedaron bajo su exclusiva responsabilidad, sin compartir pérdidas o ganancias con socio alguno. Comienza, entonces, el período de máximo apogeo del comercio de los Cinco Gremios con las colonias americanas. Hasta 1784 el tráfico se hizo dentro de las líneas trazadas en los años anteriores. La mayor parte de los embarques se hacían en Cádiz, para ser entregados en América, por medio de comisionados, a comerciantes locales encargados de su distribución. Por cierto, el volumen de los negocios aumentó considerablemente, para lo cual dispusieron incluso de navíos propios, pero se mantuvo hasta esa fecha en el esquema que habían tenido cuando operaron con los Ustáriz.

El fuerte crecimiento de los negocios les obligó, sin embargo, a intentar en 1784 una nueva modalidad. Siguiendo el procedimiento que ya habían empleado en Europa y el ejemplo de casi todas las grandes compañías que operaban en América, decidieron instalar sus propias factorías en los principales centros americanos, dando origen a una nueva etapa en sus relaciones con ellos (22). Las primeras factorías fueron las de Veracruz, México y Arequipa, instaladas en 1784. Dos años más tarde abrieron una en Lima; en 1793 otra en Guatemala (dependiente de la de México); más tarde una en Manila y, poco después, una casa en Buenos Aires (23). Aprovechando el término del monopolio que hasta entonces había tenido Cádiz iniciaron, por esos mismos años, exportaciones directas desde otros puertos españoles. Una parte importante de sus negocios, se desvió hacia Barcelona, desde donde fletaban aguardiente con destino a Veracruz y La Habana (24).

El propósito de instalar factorías en América obedecía no sólo al deseo de agilizar los negocios, sino al interés de intervenir profusamente en ellos. Cada factoría era una verdadera base de operaciones que irrumpía en el comercio local, tratando de llegar lo más lejos posible. El caso más ilustrativo es, tal vez, el de Arequipa. Aparentemente, Arequipa era menos atractiva que otros centros urbanos del continente. Sin embargo, junto con constituir

(22) El sistema de factorías fue adoptado por casi todas las grandes compañías que operaron en América. Para citar algunos casos, véase Tos estudios de Lourdes María Díaz-Trechuelo, La Real Compañía de Filipinas, Sevilla, 1975, y Bibiano Torres, La Compañia Gaditana de Negros. Sevilla, 1973.

(23) Capella y Matilla, [4], págs. 283 y siguientes.

(24) Diversos expedientes sobre esta materia, en AGI, Indiferente General, legs. 1622 y 1623. 
una puerta de entrada al Alto Perú, ofrecía la posibilidad de establecer contactos con los productores de lana de alpaca, artículo que los Gremios necesitaban para sus fábricas en España. Más tarde intentaron establecerse en Potosí. Aunque fracasaron en ese intento, parece claro que Arequipa no les interesaba tanto por sí misma, sino como una base de operaciones para intervenir en el comercio interior y obtener una materia prima para sus fábricas en la Península (25).

La propia factoría de Lima tenía la tarea de capturar el mercado guayaquileño, importante también por los envíos de cacao que se hacían desde allí. Desde Lima se pensó, incluso, llevar mercaderías por el Pacífico hasta California (26). Cada factoría era, pues, un mecanismo de penetración que los Gremios deseaban manejar con extremo cuidado, para lo cual seguían contando con el apoyo de la Corona.

En este sentido también merece una consideración la factoría que instalaron en Manila. Se puede decir que ésta resultó de una suerte de prolongación de los negocios que tenían en México. Hasta allá llevaban aguardiente, que originalmente importaban a Nueva España, y traían géneros de China que vendían en México (27). Para controlar este comercio se unieron en 1797 con la

(25) Medrano y Malamud muestran sorpresa por la temprana instalación de la factoría de Arequipa. [12], págs. 427-431. Ofrecen dos explicaciones: el deseo de vincularse al Alto Perú y la intención de evitar el enfrentamiento con los comerciantes limeños. Kendall W. BROWN argumenta que la llegada de los Gremios a Arequipa refleja las potencialidades de la zona y que éstos resumen nítidamente la filosofia mercantilista de los Borbones, por cuanto el sur peruano proporcionaba un excelente mercado para la industria española. Bourbons and Brandy. Imperial Reform in Eighteenth Century Arequipa. Alburquerque, 1985, págs. 168-169). John Fisher avala los planteamientos de Brown al insistir en que el propósito de los Gremios era intervenir en el comercio regional que se extendía, como bien sabe, hasta el Alto Perú, a pesar de la creación del virreinato de Buenos Aires. Commercial relations between Spain and Spanish America in the free trade, 1778-176, Liverpool, 1985, pág. 80. Sobre Arequipa véase, también, el libro de Alberto Flores-Galindo, A requipa y el sur andino, siglo XVIII-XX. Lima, 1977, la tesis doctoral de Eusebio QuIROz, Aspectos económicos de la Independencia de Arequipa, (Universidad de San Agustín de Arequipa, 1975) y su más reciente artículo "Historia económica regional del sur del Perú". En Realidad Económica, núm. 2, Universidad Nacional de San Agustín de Arequipa, 1990. También aporta interesantes noticias sobre la economía del sur peruano el trabajo de Magnus Mörner, Perfil de la sociedad rural del Cuzco a fines de la Colonia, Lima, 1978. Sobre las lanas de Arequipa se puede consultar el libro de Manuel Burga y Wilson ReATEGU, Lanas y capital mercantil en el sur. La casa Ricketts, 1895-1935 Lima, 1981.

(26) El expediente relativo al embarque de aguardiente y otras manufacturas en el navio Levante con destino al Callao y su trasbordo a otro para los puertos de San Blas y California, 1794, AGI, Indiferente General, leg. 1623.

(27) AGI, Indiferente General, legs. 1622 y 1623.

R. I., 1991, n 192 
Compañía de Filipinas, fundada en 1785 para atender el tráfico con Oriente. Esta fusión les permitió disponer de todas sus instalaciones, tanto en América como en Manila, este último, punto neurálgico con el comercio con Filipinas (28).

Sin duda, la instalación de factorías amplió considerablemente el campo de operaciones de los Cinco Gremios, pero, estuvieron muy lejos de responder a las espectativas cifradas en ellas. Los problemas fueron de doble naturaleza. En primer lugar, habría que considerar los fraudes y desinteligencias entre los encargados de las factorías, los negocios mal hechos, el crédito otorgado sin ninguna precaución y, en general, la deficiente administración de una empresa que requería, por su complejidad, exactamente lo contrario. En segundo lugar, hay que tener en cuenta la reacción que causó en las colonias una compañía prácticamente destinada a barrer con los comerciantes cobijados en los consulados locales. El caso mejor documentado es el de la factoría de Lima. Como se sabe, ésta se instaló en 1786, dos años después de haber recibido los directores en Madrid unas Noticias del Comercio del Perú, dirigidas, precisamente, a los Cinco Gremios y firmadas por "un buen patriota español de aquella América», que los instaba a establecerse en la capital del virreinato (29). En este documento su autor se extrañaba del olvido en que los Gremios habían mantenido al Perú, «el que por su abundancia, merece no menos atención que el de Nueva España». Aunque reconocía que el comercio del virreinato no eran tan vasto, el buen patriota español manifestaba que

puede producir más utilidades si se actúa con las precauciones, avisos y prudencia que exigen la variedad de usos y modas continuas de aquellas gentes, cuyo lujo producen buenas ganancias, como lo acreditan las espantosas ventas que en esta última guerra se hicieron, hasta el punto de llegar a pagar una mujer 25 pesos por un par de medias.

Según este mismo consejero, todo el comercio del Perú estaba en manos de españoles honrados, pero pobres, obligados a recurrir a comerciantes extranjeros instalados en Cádiz para operar en América. Si tenían éxito, podían volver a España a disfrutar de las ganancias; si fracasaban, cosa muy corriente, se veían condenados a residir en el Perú por tiempo indefinido. De todo

(28) Díaz-TREchuelo, [22].

(29) MB, Sección MS. Add. 13981. 
riesgo quedarían exentos los Gremios por el caudal de sus fondos y la diversidad de géneros que comercializaban.

Aparte de una serie de recomendaciones que no viene al caso repetir aquí, el buen patriota español se refirió a hechos concretos que aconsejaban la instalación en Lima. En primer lugar, tocó el punto relativo a la supresión de los «repartos». La medida abría enormes posibilidades al comercio, porque liberaba a los indígenas de tener que tratar con los antiguos corregidores, los cuales terminaron dominando a voluntad su poder de compra (30). La creación del virreinato de Buenos Aires había reducido ese mercado, pero, decía el autor de las «Noticias», aún era posible competir con los comerciantes del Río de la Plata, sobre todo tratándose de una corporación como la de los Cinco Gremios. Y en esto no dejaba de tener razón, pues, a pesar de la creación del nuevo virreinato, todavía hacia 1790 una parte importante del comercio con el Alto Perú, se hacía por Arequipa, asunto, por lo demás, que los Gremios sabían muy bien. Una factoría en Lima serviría también, seguía planteando el patriota español, para la recalada de los barcos que iban a China y Filipinas, con notables ventajas para el comercio peruano (31). El consumo de suntuarios, el control que se podía ejercer sobre Chile y Guayaquil y los interesantes márgenes de utilidad que dejaban las especulaciones en estos parajes, fueron argumentos que el autor también esgrimió para convencer a los Gremios que se instalaran en Lima.

A pesar de los pronósticos, la factoría de Lima terminó en el más completo fracaso. Las causas que lo provocaron fueron las mismas que perjudicaron sus progresos en otras partes de América. Por este motivo, su caso se puede analizar desde una perspectiva más amplia. En el plano de la administración interna, los responsables de la factoría se comportaron de un modo que poco contribuyó al éxito de la empresa. Instalados en Lima, más se preocuparon por acrecentar su propio caudal que el de la Compañía, debiendo algunos ser separados de sus cargos en medio de acusaciones que dieron origen a largos y costosos

(30) Jurgen GolTE, Repartos y rebeliones. Tupac Amaru y las contradiciones de la economia colonial, Lima, 1980.

(31) Conviene recordar que en el siglo XVIII el comercio con el Asia no era ajeno a las colonias americanas, situación que parece haber conocido muy bien el autor del documento. Sobre el tráfico aludido véase Sergio VILLALoBos, Comercio y contrabando en el Río de la Plata y Chile, Buenos Aires, 1965, pág. 61-65. 
pleitos (32). El crédito también fue otorgado con excesiva generosidad, sumando de udas que nunca se pudieron cobrar enteramente y que, con el correr de los años, pasaron a constituir pérdidas que la Compañía no pudo absorber. El problema tenía su origen en el proc edimiento empleado para retribuir a los encargados de las fac torías. Estos no cobraban sueldos, sino un determinado porcenta je de las ventas. Así, pues, lo único que les interesaba era aumen tarlas, asegurándose el porcentaje que les correspondía en el primer pago que hacían los comerciantes, sin importarles después lo que ocurría con los saldos insolutos. Este fue un problema que la Compañía tampoco pudo resolver y que se tradujo en otros tantos pleitos que muy poco aportaron a la institución.

Sin embargo, más complejo fue el problema que se derivó de la oposición que encontró la Compañía en los comerciantes locales, cuyos privilegios empezó a amagar. En Lima, como en otras partes de América, la defensa de estos últimos se canalizó a través del Consulado. Un extenso memorial presentado en Madrid el 28 de diciembre de 1793 por don Antonio Bustillos de Ceballos, precisamente en nombre del Consulado de Lima, permite conocer la posición de los com erciantes limeños (33). Las primeras quejas se orientaron a denunciar las funestas consecuencias que había tenido para el comercio limeño el aumento de las expediciones por el cabo de Hornos, la habilitación de nuevos puertos en el Mar del Sur, la internación de mercaderías por Buenos Aires y, últimamente, la libertad de comercio. A estos males, señalaba Bustillos, habría que agregar ahora la instalación de la factoría de Lima. Según los cálculos del Consulado, en los tres primeros años, ésta había intro ducido mercaderías por un valor similar a la mitad de la mone da acuñada en el Perú, amenazando con llegar a absorberla en teramente.

El Consulado cons deraba que un proyecto de esta naturaleza era no sólo una ame naza para los comerciantes de Lima, sino una palanca que provocaría la ruina de los que operaban en las demás provincias, por la costumbre de los comisionados de vender al menudeo al $\mathrm{m}$ ismo precio que al por mayor. Del control

(32) Véase, por ejemplo, carta de José López a S.M. de 28 enero 1804 y Compendio o extracto de las tropelias y excesos verificados por los directores de los Cinco Gremios Mayores de Madrid y por comisión de ellos contra don Gaspar Rico y don Antonio Tararaco, socios y apoderados de la Compañia en el Perú, Lima, 1811. Un ejemplar ale este impreso y la carta citada en AGI, Indiferente General, leg. 1623.

(33) AGI, Indiferente General, leg. 1623. 
de las importaciones, decía Bustillos, pasarían al control de las exportaciones, con los consiguientes daños para cuantos vivían ocupados en esos oficios. En su opinión la presencia de la Compañía presagiaba un futuro muy incierto para una región que había recibido ya demasiados golpes.

Más allá de la defensa que los comerciantes limeños hacían del monopolio y de los privilegios que habían tenido hasta el tercer cuarto del siglo XVIII, la discusión de los planteamientos del Consulado, nos permite aproximarnos a otros aspectos de la economía peruana que se han venido comentando en los últimos años. Se sabe que en el siglo XVIII se desarrolló en el Perú un sistema económico que tenía como eje los llamados urepartimientos de efectos». Dichos "repartimientos", basados en la capacidad del corregidor de colocar mercaderías entre los indígenas y extraer excedentes de las comunidades locales, contaban con el apoyo de los grupos vinculados al comercio y de la propia Corona. A través de ellos, los comerciantes aumentaban sus ganancias mediante un sistema que permitía un comercio exterior e interior cada vez más intenso, mientras la Corona obtenía nuevos ingresos a través de la venta de los cargos (34). Los propios "kurakas», integrados al sistema, empezaron a servir de puente entre los comerciantes y la población indígena, adoptando una función muy diferente a la que habían tenido en el siglo XVI (35).

A pesar del aparente dinamismo que cobró la economía, el sistema de repartos despertó muy pronto la resistencia de la población aborígen y de los pequeños y medianos comerciantes del interior. Para los primeros era cada vez más difícil aprovechar los productos que recibían de los corregidores y, para los segundos, competir con un mecanismo de control que estaba sofocando a las economías locales. Como ha sugerido Golte, de estos conflictos surgieron las rebeliones que sacudieron al virreinato al promediar la segunda mitad del XVIII y que decidieron a la Corona a terminar con un sistema tan resistido (36).

La supresión de los repartos fue, sin duda, un duro golpe para los comerciantes limeños y para todo el sistema económico que había girado en torno a estos. Por este motivo, algunos

(34) GoLTE, [30], págs. 14-15.

(35) Karin Spalding, De indio a campesino. Cambios en la estructura social del Perú Colonial, Lima, 1974, pág. 54. Véase, también, Natham WACHTEL, Sociedad e Ideología. Ensayos de Historia y Antropología Andinas, Lima, 1973, págs. 81 y siguientes.

(36) Golte [30]. 
funcionarios miraron con nostalgia su abolición. En 1784 el visitador Jorge Escobedo no vaciló en proponer su reimplantación, con algunas reformas que los hicieran más justos (37). Escobedo escuchaba con atención las quejas del Consulado, no porque viera con desagrado las últimas reformas, incluida la libertad de comercio, sino porque comprendía muy bien que el principal problema del Perú estaba en la falta de medios de pago que evitaran la extracción de moneda (38). De alguna manera, los repartos habían obligado a la población indígena a producir bienes para el intercambio. Escobedo presentía que su término se traduciría en ociosidad y en una decadencia general que veía con preocupación (39).

Frente al vacío dejado por la supresión de los repartos, otras autoridades pensaron en soluciones diferentes. El virrey Francisco Gil y Lemos, a quien el Consulado también había dirigido su representación contra los Cinco Gremios, asumió una posición muy clara. Gil era un decidido partidario de la libertad de comercio. Para él, la escasa internación y circulación de efectos españoles en el Perú era la causa por la cual las manufacturas del Cuzco copaban el mercado local, con notable perjuicio para la agricultura, industria y marina peninsulares (40). Por esta razón, apoyó con entusiasmo la instalación de la Compañía de los Cinco Gremios y con el mismo entusiasmo celebró la supresión de los repartos, descalificando las quejas de los comerciantes por infundadas y contrarias a la libertad de comercio:

Los corregidores han sido por muchos años los proveedores no de las cosas útiles y acomodadas al gusto de los consumidores, sino de las que convenían a sus granjerías o a los intereses de los que los habilitan. La exclusión con que hacían este mo-

(37) Pablo Macera, Introducción a Reforma del Perú, de Alonso Carrió de la Vandera Lima, 1966. Citado por GolTE [30], pág. 294.

(38) Cuenta del Superintendente de Real Hacienda don Jorge Escobedo respecto de un informe del Consulado sobre el estado del comercio de Lima, Lima, 5.9.1788, AGI, leg. 1546. Escobedo lamentaba que de 28 retornos del Callao a Cádiz entre 1784 y 1788, sólo se había embarcado cobre de Coquimbo, cascarilla y cacao de Guayaquil, añil y lanas de vicuña y carnero.

(39) Esta preocupación de Escobedo ha sido destacada ya por un estudioso del tema. Véase Alfred• Moreno Cebrián, El corregidor de indios y la economía peruana en el siglo XVIII. Madrid, 1977, págs. 642-645.

(40) Informe del Consulado sobre el comercio de Lima, Lima, 20 diciembre 1790. AGI, Audiencia de Lima, leg. 1547. 
nopolio y los vicios de los repartimientos ha dejado una especie de males, cuya reparación necesita mucho tiempo, muchas casualidades felices y muchas atenciones del gobierno (41).

Una de esas casualidades felices era, precisamente para Gil y Lemos, la instalación de las factorías de los Cinco Gremios, porque cuando en toda América, señala el virrey, se logre lo que proyecta la Compañía para el Perú, «entonces no se echarán menos los repartimientos tan justamente prohibidos» (42). Así pues, las factorías de los Gremios parecían como una excelente alternativa para reemplazar un mecanismo, cuya abolición dejaba un vacío que preocupaba a ciertas autoridades.

Esta situación no pasó inadvertida en otras regiones del Perú. El cabildo de Arequipa, a través del síndico Agustín Abrilloy, lanzó en 1792 quemantes acusaciones contra los Gremios. Con la llegada de éstos, decía Abrilloy, todo se ha transtornado, esta sola casa "introduce toda la ropa que surte esta plaza", dejando en el más completo desamparo a los 350 ó 400 comercianțes de

(41) Expediente relativo a la petición del Consulado de Lima para que se suspenda la remesa de géneros a las factorías de los Cinco Gremios. Lima, 6 abril 1796. AGI, Indiferente General, leg. 1623. La preocupación del virrey Gil por la competencia que hacían los productos locales a los que se traian de España, se justifica plenamente si se tiene en cuenta algunos valores del comercio en ciertas regiones del virreinato. En Copiapó, corregimiento del norte de Chile, el $60 \%$ de los productos que vendía un mercader de la zona, eran de procedencia americana, Jorge PinTo, "Un mercado interior en Chile Colonial: el corregimiento de Copiapó en el siglo XVIII". En Julio Brolly y Jorge PINTo, Copiapó en el siglo XVIII, Valparaíso, 1988, TANDETER y WACHTEL, refiriéndose a Potosí, hablan de cuatro niveles o coyunturas económicas: la oceánica o europea, la americana, la regional y la local. Las tres últimas dejaban poco espacio a la primera y, aún en ésta, los productos procedentes de otros países europeos un espacio todavía menor a los españoles. Precios y producción agraria. Potosí y Charcas en el siglo XVIII. Buenos Aires, 1983. También es interesante el estudio de Silvia Palomeoue, "Loja en el mercado interno colonial", en Hisla, núm. 2, Lima, 1983, págs. 33-45; y el de Magdalena ChOCANo, "Circuitos comerciales y auge minero en la Sierra Central". En Allpanchis, vol. XVIII, núm. 21, Cusco, 1983. Para una bibliografía sobre el tema véase Verónica VEerkamp, "Bibliografía sobre mercados y comercio". En América Indigena, vol. XLII, núm. 2. México, 1982, págs. 467-504.

(42) Idem. Sobre la polémica que despertó la abolición de los repartos véase, también, John LYNCH, La administración colonial española, 1782-1810, Buenos Aires, 1962, págs. 59-60 y 182-185; Edberto Ackevedo, "El establecimiento de las intendencias en el Alto Perú", en Investigaciones y Ensayos, núm. 26, Buenos Aires, 1979, págs. 213-258; y John FISHER, Gobierno y sociedad en el Perú Colonial. Lima, 1981, págss. 25-40 y 102.

R. I., $1991, \mathrm{n}^{9} 192$ 
la provincia (43). En realidad, a los comerciantes arequipeños les interesaba una sola cosa: defender su comercio que ellos controlaban y que giraba en torno a las importaciones que hacían los mercaderes limeños, de quienes obtenían las mercaderías que negociaban en el sur y Alto Perú. Más que estorbarles la presencia de los Gremios en el país, les preocupaba su instalación en Arequipa. No tenían problemas para admitir la factoría de Lima; por el contrario, se puede decir que la miraban con simpatía, en tanto reemplazaba allí a sus antiguos proveedores, otorgándoles mayores facilidades. Pero, lo que no querían por ningún motivo era tenerlos en Arequipa, donde amenazaban convertirse en competidores difíciles de doblegar (44). Para expulsarlos, argumentaron que fomentaban el lujo y la vanidad y que comercializaban con los productos de la tierra tal como lo habían hecho antes los corregidores. Ni más ni menos, agregaba el cabildo de Arequipa, "los comisionados de la casa de los Gremios han hecho y están haciendo un perfecto repartimiento" (45).

$Y$ de esto se daba cuenta Gil y Lemos, con la diferencia que él los consideraba una excelente alternativa para reemplazar a los corregidores. En tal sentido, las razones que esgrimía el cabildo para expulsarlos de la ciudad, eran las mismas que argumentaba el virrey para apoyarlos con tanta decisión. Del rol podían jugar las grandes compañías comerciales en América, creo que hubo conciencia en las esferas del gobierno peninsular, especialmente en el caso de los Cinco Gremios. Esto explica las facilidades que encontraron para sus gestiones y la forma como fueron tratados por autoridades tan influyentes en América como el virrey Gil y Lemos. Suprimidos los repartimientos, eran una especie de tabla de salvación para reactivar la economía. En esta dirección, Gil representaba una corriente extrema: aquella que miraba sólo los intereses de la Corona y de los grupos que giraban a su alrededor, uno de los cuales era, justamente, el de

(43) Testimonio que contiene el informe que los miembros del cabildo, justicia y regimiento de la ciudad de Arequipa emitieron en conformidad del superior decreto de 23 abril 1791 acerca del establecimiento de casas factorías que pretenden establecer los apoderados de los Cinco Gremios Mayores de Madrid. Parecer del síndico o procurador de Arequipa. Arequipa, 25 septiembre 1792. AGN, Real Tribunal del Consulado, vol. 249, leg. 11. Sobre esta misma materia véase el legajo 10 del mismo volumen y el volumen 250.

(44) BROWN [25] y Fischer [25], han destacado el rol competitivo que jugaron los Cinco Gremios en Arequipa para los comerciantes locales. Fischer señala que a éstos no les quedó otra alternativa que adaptarse a ese entorno de competencia que impuso la Compañía.

(45) Testimonio que contiene el informe que los miembros del cabildo, justicia y regimiento de la ciudad de Arequipa. 
los Cinco Gremios. Conscientes éstos del papel que se les asignaba, no se cansaban de repetir que el último resultado de su gestión "debía ser en nuestra Península el progreso de las artes, el fomento de la agricultura, la mayor rapidez de la circulación y el consecuente incremento de la real hacienda" (46). De este modo, seguían comprometiendo a los funcionarios que veían en ellos un instrumento eficaz para impulsar el desarrollo de España.

El antecesor de Virrey Gil, Teodoro de Croix, quien también tuvo que hacerse cargo de las quejas del Consulado contra la libertad de comercio, había tenido una posición más o menos similar. Croix, con una larga experiencia en la administración colonial -entre otras cosas, le había correspondido dirigir el virreinato de Nueva España durante la visita de José de Gálvezcomprendía que el clamor de los comerciantes limeños obedecía al deseo de conservar los privilegios que habían gozado hasta entonces (47). Sin embargo, coincidiendo con Escobedo, miró las cosas desde una perspectiva más amplia. La libertad de Comercio, decía el virrey,

será útil en cuanto influya en el aumento de frutos que sirvan de equivalente en las compras, trueques o permutas que se hagan con los efectos europeos. Pues, de otra manera, ¿de qué nos servirá la libertad? Para conducir a España todo el oro y plata que se saca de estas provincias, basta y sobra un solo navío (48).

Sacar oro y plata, agregaba Croix, podría ser beneficioso para la metrópoli: pero, sólo en el corto plazo, al final siempre será perjudicial. Proponía dejar recursos a los americanos y, sobre todo, resolver el problema de la falta de mano de obra. En cuanto a la libertad de comercio, no tenía dudas de su utilidad. Liberalizando el comercio, señalaba categóricamente, se abrirán las puertas a los productos españoles y se acabará la competencia

(46) Comunicación de los directores Domingo de Altube y Diego de Palacios. Madrid, 2 julio 1800, AGI, Indiferente General, leg. 1623.

(47) Los clamores de los comerciantes limeños, decía el virrey, obedecen al "deseo ardientísmo de que esta capital [Lima], sea el emporio del comercio y que los demás comerciantes del virreinato, Chile, Guayaquil, no comercien sino por sus manos". Comunicación del virrey del Perú sobre solicitud del consulado se suspenda la entrada del barco al Callao por dos años y se prohiba la internación de mercaderias por Buenos Aires. Lima, 6 agosto 1787. AGI, Audiencia de Lima, Lima, leg. 1546.

(48) Ibidem. 
que las telas americanas hacía a las que llegaban de España (49). El porvenir del Perú, seguía Croix, está en la minería. Para fomentarla proponía la creación de bancos de rescates y limitar el comercio. En lo último coincidía con el Consulado, no porque dejara de pensar que lo único que interesaba a los comerciantes limeños era la defensa de sus privilegios, sino, porque suponía que la profusión de éste provocaba la fuga de recursos que el país necesitaban para diversificar su economía. El problema para el Perú consistía en que Croix, como muchos de sus coetáneos, entendieron por diversificar alentar la minería o cualquier producción que no compitiera con lo que se traía desde España. Eran los límites que se imponían a una economía colonial, irrenunciables para los Borbones y sus administradores en América.

Estos asuntos se siguieron discutiendo en los años siguientes. En 1794, José Ignacio Lequanda, contador de la Real Aduana de Lima, en su Idea Sucinta del Comercio de Lima, proponía revisar la situación en que se encontraban los obrajes del Perú. Después de sugerir y comentar varias soluciones, era de opinión prohibir que los hombres se ocuparan en tareas que podían correr por cuenta de mujeres, jóvenes y minusválidos. Lequanda quería, además, evitar que se siguiera explotando a la mano de obra en unas "fábricas" que consideraba verdaderas "cárceles perpetuas» y favorecer a la minería, por cuanto desplazaría hacia esa actividad la mano de obra ocupada en los obrajes. Pensaba, también, que con esto se estimularía a la industria española, pues tendría un mercado libre de competidores. Firme partidario de la libertad de comercio, abogaba, sin embargo, por el envío equilibrado de

(49) Croix planteó su punto de vista con toda claridad. En su comunicación desde Lima el 16 agosto 1787 indicaba al ser consultado sobre esta materia

"Pero, la mayor utilidad que se seguirá al comercio y al estado, es el golpe mortal que podrán recibir la multitud de obrajes, o sean fábricas de géneros bastos y groseros que se labran tanto en Quito, como en el Cuzco, Guamanga y otras muchas partes, de cuyos efectos se visten todos los indios y mestizos, todos los esclavos y todas las personas de una suerte mediana e infeliz. Porque viéndose más baratos que los géneros bastos de las fábricas de España, se desprecian éstos y se apetecen y compra aquéllos. ¡Qué impulso y fomento recibirán nuestras fabricas! ¡Qué extensión al comercio! ¡Qué aumento la marinería! España no puede perder de vista la destrucción y ruina de estos obrajes".

Sobre esto mismo, véase, FISHER, [42] págs. 147-159. 
mercaderías, con el objeto de evitar la saturación del mercado y las consiguientes pérdidas para los productores y la Corona (50).

Tres años antes, Joseph Baquíjano y Carrillo había expresado la misma confianza de Lequanda en la minería, como instrumento de progreso para el Perú y recomendado la necesidad de regular las importaciones, con el propósito de evitar las «quejas y clamores con que quiere degradarse el útil y provechoso sistema de la libertad». En esa oportunidad, planteó con toda claridad que buena parte de las quejas se dirigían contra las grandes compañías comerciales, principalmente contra la de Filipinas y los Cinco Gremios. Aunque reconoció que éstas debían gravar sus negocios con los costos propios de las grandes empresas, no dejó de reconocer que sus progresos whan sido generalmente la ruina y extinción del comercio particular». Por último, no dejó de reconocer el peligro que encerraba el excesivo crecimiento de las importaciones que se produjo después del decreto de libre comercio, de 1778, no por efecto de la libertad, sino como resultado del fervor que produjo la novedad (51).

La saturación del mercado fue un problema del cual no se pudo sustraer el propio Gil. Al término de su gobierno tuvo que admitir que la presencia de los Cinco Gremios no podía menos que preocupar a las autoridades, por el daño que estaban ocasionando al comercio limeño, a causa del exceso de mercaderías que internaban. A pesar de que mantenía su confianza en las ventajas del libre comercio, la opinión de los organismos y personas que consultó, lo convencieron de que era necesario limitar la gestión de la Compañía (52).

Este fue el terreno en que se movieron las factorías de los Cinco Gremios Mayores de Madrid en el Perú. Resistidas y hostigadas por los comerciantes locales, contaron, en cambio, con el apoyo de aquellas autoridades que veían en ellos un elemento dinamizador de la economía metropolitana, desde el momento

(50) MB, Manuscrito, Eg. 771. Sobre los obrajes ecuatorianos, véase el libro de José María VARGAS, Economía politica del Ecuador durante la Colonia, Quito, 1975; y sobre los peruanos y altoperuanos los trabajos de Fernando SILva SANTISTEBAN, "Los obrajes en el virreinato del Perú". Lima 1964; Tecnología Andina, Introducción, selección y comentarios de Rogger RAVINES, Lima, 1978, págs. 347367, y Mary MONEY, Los obrajes, el traje y el comercio de ropa en la Audiencia de Charcas. La Paz, 1983.

(51) Disertación histórica y política sobre el comercio del Perú. En El Mercurio Peruano, Tomo I, Lima, 1964, págs. 237 y 255.

(52) Memorias de los virreyes que han gobernado el Perú durante el tiempo del coloniaje español, tomo VI, Fray don Francisco Gil de Tobada y Lemos, Callao, Lima, 1859, págs. 114-129. 
en que sus formas de operar reflejaban nítidamente la filosofía mercantilista que imperaba en la España del siglo XVIII (53). Los estudios que se han hecho sobre el comercio colonial en estas dos últimas décadas lo confirman plenamente.

De acuerdo a las cifras que entrega García-Baquero, a lo largo del XVIII se produjo en España un aumento de las exportaciones industriales hacia América, basado en el aumento de las exportaciones textiles, que en conjunto llegaron, en los años previos al decreto de libre comercio, a poco más del $51 \%$ de las exportaciones totales de la Península (54). Sin duda, este incremento era el resultado del aumento de la producción española, cuyo consumo dependía, en cierta medida, de la capacidad del mercado americano, transformado en un verdadero estímulo, especialmente para las manufacturas catalanas (55). En este sentido, la opinión de las autoridades en América coincidía exactamente con los criterios formulados por las autoridades peninsulares y, a la larga, con la política que se adoptó. Así, pues, nada podía ser más útil para la Corona que abrir las puertas en las colonias a una institución como los Cinco Gremios, capaces de exportar lo que se producía en España y capaces también de penetrar las articulaciones internas que se habían tejido en las colonias americanas, precisamente en el momento en que la abolición de los repartos rompía tales articulaciones.

Tengo la impresión que los repartos que hacían los corregidores empezaron a ser percibidos en España como un obstáculo que limitaba las posibilidades del mercado colonial, al dejarlo en poder de mercaderes locales o intermediarios de segundo orden que lo mantenían en un esquema demasido estrecho para el dinamismo que requería la expansión de la producción española. Creo que aquí está la clave para entender el apoyo que recibieron los Gremios por parte de la Corona y de las autoridades americanas y la oposición que encontraron en los consulados locales, siempre reticentes a admitir reformas que alteraran el marco en el cual había funcionado el comercio hispanoamericano (56). Ilus-

(53) Brown [25], pág. 169.

(54) García-BaOuero, Cádiz y el Atlántico, [1] págs. 330 y siguientes.

(55) AnÉs [1], El Antiguo Régimen, pág. 204. Véase, también el trabajo de Carlos MarTínez Shaw [1].

(56) Eduardo Arcila, El Real Consulado de Caracas, Caracas, 1957; Sergio Villalobos, El comercio y la crisis colonial, Santiago, 1968; David BRADING, Mineros $y$ comerciantes en el México Borbónico, (1763-1810) Madrid, 1975. Para el caso particular del comercio peruano, pueden verse también los diferentes informes aparecidos en El Mercurio Peruano, 13 vols. Lima, 1964-1979. 
tra, también, los problemas de fondo que se esconden, detrás de las opiniones de Escobedo, Gil, Croix, Lequanda y Baquíjano y, yendo más lejos, el transfondo de las reformas de la segunda mitad del siglo XVIII, detrás de las cuales debieron estar las burguesías periféricas, principalmente la catalana, interesadas en obtener ventajas que favorecieran su desarrollo (57). Es probable que la propia abolición de los repartos haya tenido más relación con los intereses de aquellos grupos que con las rebeliones indígenas del último siglo colonial. Al término de su dominación en América, España luchaba por recuperar un mercado que se le había escapado de las manos. Las grandes compañías comerciales podían ayudar a conseguirlo; sin embarge, los hechos probarían más tarde que los dados ya estaban lanzados.

\section{El CASO MEXICANO}

Los estudios que se han hecho sobre el comercio mexican sugieren que las factorías de los Cinco Gremios se desenvolvieron allí en condiciones parecidas a las del Perú. Con anterioridad a las reformas del XVIII, el comercio novohispano había girado en torno a la feria de Jalapa, lugar hasta el cual acudían los grandes comerciantes a comprar mercaderías que luego vendían en Ciudad de México y en otros puntos del país (58). Se trataba de mercaderes que intervenían tanto en el comercio exterior como en el comercio interior, invadiendo todas sus esferas. Como ha dicho Pérez Herrero, más que comerciantes eran, en realidad, hombres de negocios (59). Así como en el Perú los comerciantes se habían aprovechado de los corregidores para ampliar sus operaciones, en Nueva España recurrieron a los alcaldes mayores (60). Gálvez tuvo oportunidad de comprobarlo durante la visita que hizo al virreinato entre 1765 y 1771, formándose una opinión muy poco favorable de aquellos funcionarios.

(57) J. Vicens Vives, Coyuntura económica y reformismo burgués, [1], pág. 25. Véase además, V. VÁzoUEz DE PRADA, "Las rutas comerciales entre España y America en el siglo XVIII". En Rutas del Atlántico, $9^{\circ}$ Coloquio Internacional de Historia Marítima. Sevilla, sept. 1967, págs. 210-211; y Carlos Martínez Shaw, Cataluña en la carrera de Indias, 1680-1756, Barcelona, 1981.

(58) Brading [56], págs. 183 y siguientes.

(59) Pedro Pérez Herrero, "Actitudes del consulado de México ante las reformas comerciales borbónicas (1718-1756)". En Revisia de Indias, vol. XLIII, núm. 171. Madrid, enero-junio, 1983, págs. 97-182.

(60) BRADinc; [56], pág. 76. 
San Luis Potosí y Guanajuato, escribía al virrey Croix en 1767 son provincias muy ricas, extraordinariamente favorecidas por la naturaleza y abundantes en frutos, metales y "otras exquisitas producciones». Sin embargo, decía más adelante:

caminan precipitadamente a su ruina y a igual paso corren las demás, por faltarles magistrados que las gobiernen y fomenten, pues los Alcaldes Mayores, a quienes únicamente están confiadas, ni tiene facultades para hacer bien a sus pueblos (que en realidad destruyen muchos con la mira de enriquecerse), ni son hombres por lo regular y por su infeliz suerte de quienes deba esperarse que se dediquen a promover los intereses púb!icos, ni la felicidad de los particulares, cuando a ello no se les da con que comer y se les cobra media anata con 18 por ciento de premio de un sueldo que nunca se les paga, poniéndolos de consiguiente en la triste necesidad de aplicar toda su industria para sacar con qué mantenerse y pagar los muchos empeños que traen contraídos cuando llegan a tomar posesión de sus empleos (61).

Ya en esa fecha, e insistiendo en que no se podía abandonar México «a las indiscretas manos y a la infeliz conducta de un Alcalde Mayor", Gálvez proponía la aplicación en América de la reforma de las intendencias. Un mes más tarde, en enero de 1768, con el acuerdo del marqués de Croix, del obispo de Puebla y del arzobispo de México, proponía al Rey su plan para instalar las intendencias en Nueva España. En esa ocasión reiteró sus quejas sobre los alcaldes mayores y la red de tenientes que tenían repartidos por la tierra, agobiando a la economía local y dañando seriamente los intereses de la Corona (62).

La libertad de comercio y las reformas de las intendencias dejó abiertas las puertas de Nueva España a los Cinco Gremios Mayores de Madrid. Aunque éstos estaban allí desde mediados de siglo, la apertura de la factoría de México coincide con la aplicación de las reformas borbónicas más radicales. La impresión

(61) Josep de Gálvez. Informe de la visita general de la Nueva España. Al Excmo. Señor Marqués de Croix... México, 25 díciembre 1757. MB. Manuscrito Add. 13986.

(62) Informe y plan de Intendencias para el reino de Nueva España presentado por el visitador D. José de Gálvez y el virrey marqués de Croix, y recomendado por el obispo de Puebla y el arzobispo de México. México, 16, 20 y 21 de enero de 1768. En Luis NavarRo García, Intendencias de Indias, Sevilla, 1959, págs. 164-176. 
que deja la documentación revisada sugiere que hasta el tercer cuarto del XVIII, el tráfico hacia Nueva España era una especie de prolongación del comercio con Honduras. La mayor parte de las autorizaciones concedidas por la Corte favorecían, más bien, el traslado de mercaderías hasta ese lugar. Sin embargo, ya en Honduras, los apoderados de la Compañía invocaban «la injuria de los tiempos» y la falta de "firmeza en los consumos", para trasladar los envíos a Jalapa y reclamar rebaja de las alcabalas. En retorno, embarcaban para España grano, azúcar y añil. Más tarde, el comercio con México formaba parte de la cadena que se extendía a Manila y sólo en las dos últimas décadas parece haber alcanzado sentido por sí mismo (63). Por esos años habían inaugurado la carrera Barcelona-Málaga-Veracruz, para lo cual se servían de diversos navíos que cargaban con productos que obtenía la factoría de Barcelona y los comisionados de Málaga (64). Incluso, el aumento de ese comercio causó preocupación a los comerciantes gaditanos, por la evidente saturación del mercado mexicano, controlado hasta ese momento por ellos casi sin contrapeso (65).

Más allá de los negocios coronados por el éxito, los Cinco Gremios tuvieron que enfrentar en México tres tipos de problemas:

En primer lugar habría que referirse a las operaciones mal calculadas. Es corriente encontrar en la documentación relativa a la Compañía en Nueva España solicitudes para retornar a la Península mercaderías que resultaban invendibles. Los comisionados no tenían, al parecer, un buen conocimiento de las condiciones del mercado, lo que se traducía en fracasos que afectaban a la empresa. A este hecho habrá que agregar un segundo problema que no se detecta en el Perú: la escasa disposición de las autoridades locales para concederles el apoyo que encontraron

(63) Testimonios sobre esta materia en AGI, Indiferente General, legs. 1622 y 1623.

(64) Véase, por ejemplo, Concesión hecha por el monarca para el navio Purísima Concepción, 4.5.1788. AGI, Indiferente General, leg. 1622. Uno de los productos que más les interesó llevar desde Cataluña, fue el aguardiente. En 1790 se calculaba que habian internado en México más de 20 mil barriles, cifra que para un funcionario de la aduana era considerable (Expediente relativo a la petición de Juan Antonio Martínez en nombre de la factoría de los Cinco Gremios de Veracruz para que se rebaje un cuartillo en el aforo de cada barril de aguardiente, 1790-1791. AGI, Indiferente General, leg. 1623), El aguardiente de caña y el pulque, bebidas populares en México, fueron prohibidas por las autoridades para dar cabida a las exportaciones de Cataluña. Véase José HERNÁNDEZ Palomo, El aguardiente de caña en México, (1724-1810), Sevilla, 1974.

(65) AGI, Audiencia de México, leg. 2505. 
en el sur. Por el contrario, los funcionarios del gobierno en México, presionaron a la Corona para que les diese el mismo trato que a cualquier comerciante, sin favorecerles con concesiones que los colocara en situación privilegiada. Por último, los comerciantes mexicanos cerraron filas contra ellos. Además de estorbar sus negocios, regateaban los precios cuando las mercaderías rezagadas debían salir a remate o simplemente se negaban a hacer ofertas (66). Finalmente, terminaron confinándolos a Veracruz, sin dejarles espacios para su gestión (67).

El interés de los comerciantes mexicanos por mantener las condiciones en que se había desenvuelto el comercio novohispano es fácil de comprender. Sin embargo, hay que tener presente, además que en el siglo XVIII había surgido en América una clara conciencia de los intereses locales y de la necesidad de defenderlos. Un incipiente nacionalismo y una postura precozmente antidependentista se empieza a esbozar desde el Perú a México (68). Este hecho constituía un freno para la Compañía. Al margen de toda sospecha, la hostilidad rodeó a los Gremios en los territorios ultramarinos.

\section{LAS ÚlTIMAS ACTUACIONES Y EL FIN DE LA COMPAÑÍA}

Los últimos años del dominio español en América fueron desastrosos para los Cinco Gremios. Además de los problemas derivados de la resistencia que encontraron en los consulados, tuvieron que hacer frente a la competencia del comercio inglés, en pleno ascenso a partir de la década del $80(69)$, y todas las dificultades que acarrearon al comercio trasatlántico las continuas guerras en que se vio envuelta España. La integración que buscó la Corona con sus colonias en el siglo XVIII a través del comercio, se vio, incluso, desarticulada por las guerras, abortando una

(66) Sobre esta materia me remito, una vez más, la documentación que se conserva en AGI, Indif erente General, leg. 1622 y 1623.

(67) MEdRano y MaLAmud, [2].

(68) Sara Almarza, "El comercio en el siglo XVIII: arbitrio a las autoridades". En Revista de Indias, vol. XLV, núm. 175, Madrid, enero-junio 1985, págs. 13-25

(69) Miguel IzARD, "Algunas notas sobre el comercio colonial atlántico: los intercambios del Reino Unido (1772-1808)". En Revista de Indias, año XL, núms. 159-162. Madrid, 1980, págs. 425-439. 
política de desarrollo que no tuvo ocasión de probarse (70). En el caso concreto de los Cinco Gremios, aún en 1797 no lograban cuadrar un saldo de casi 6 millones de reales, que se venía arrastrando desde los primeros años de la década, debido a la imposibilidad de verificar el estado de la factoría de Lima, por los problemas derivados de la guerra contra Inglaterra (71).

Tampoco tuvieron éxito como institución de crédito. Lohmann ha señalado que sería interesante estudiar el papel que jugaron en este campo (72). Tiene razón, porque lo manejaron ampliamente. El problema surgió para ellos cuando intentaron cobrarlo. Tuvieron, entonces dificultades no sólo con los préstamos otorgados a particulares, la mayoría hechos en mercaderías, sino también, con los entregados a las instituciones fiscales. Para citar algunos casos, basta decir que en 1792 hicieron grandes esfuerzos para recuperar 18 mil pesos entregados a préstamo a las cajas reales de La Habana, esfuerzo que repitieron sin éxito, como en el caso anterior, en 1806 frente a las cajas fuertes de Buenos Aires, a las cuales habían otorgado dos libranzas por $50 \mathrm{mil}$ pesos cada una (73).

Hacia 1800 se calculaba que los haberes y débitos de la Compañía en Lima sumaban unos 400 millones de reales, difíciles de recuperar por los trastornos que había sufrido el país, debido a la última guerra. Los nuevos factores, que llegaron al año siguiente, traían instrucciones para agilizar los cobros. Para ello lograron que el virrey autorizara la formación de una comisión integrada por dos oidores de la audiencia y dos comerciantes; sin embargo, tampoco tuvieron éxito (74). En 1834, la totalidad del crédito otorgado mientras operó la Compañía sumaba poco más de 652 millones de reales de vellón, de los cuales 349 estaba en

(70) Miguel IZARD, "Comercio libre, guerras coloniales y mercado americano". [1]. Véase, también, el artículo de Anthony MacFarlane, "El comercio exterior del virreinato de la Nueva Granada: conflictos en la política económica de los borbones, 1873-1789". En Anuario Colombino de Historia Social y de la Cultura, núms. 6-7, Bogotá, 1971-1972, págs. 69-116.

(71) Cuenta de los cuatro años comprendidos entre el 1 enero 1790 y el 31 diciembre 1793. Madrid, 16.12.1797. MB, SM. Eg. 513.

(72) Guillermo LoHmann Villena, "Banca y crédito en la historia española. Nutas sobre hipótesis y fuentes informativas", En Historia, núm. 8, Santiago, 1969, págs. 289-307.

(73) Expedientes relativos a las cobranzas de los Cinco Gremios. AGI, Indiferente General, leg. 1623. Para ilustrar mejor esta situación, vale la pena decir que la deuda de las cajas reales de Buenos Aires se seguía cobrando en 1830.

(74) Pleito entre los diputados de los Cinco Gremios de Madrid y los comisionados Gaspar Rico y Antonio Taranco, 1800-1801. AGI, Indiferente General, leg. 1623. 
poder de la hacienda real y 164 en manos de comerciantes que habían pactado con la antigua factoría de Cádiz y los comisionados en América. Hacia esa fecha, la deuda se consideraba irrecuperable (75).

En algunas factorías americanas se desataron, además verdaderos escándalos, dando paso a bullados procesos. En 1812, Manuel Rodríguez y Valle, uno de los socios principales, se refirió extensamente a la factoría de Lima. Esta había sido encargada en 1801 a Gaspar Rico y Antonio Ortiz de Taranco, quienes al poco tiempo se apropiaron de gruesas sumas de dinero (76). La conducta de ambos había merecido severas quejas de las autoridades peruanas y de los propios directores. Estos últimos se vieron obligados a llamarles la atención porque vivían "escandalosamente, entregados a vicios vergonzosos y devoradores que les degradan y nos perjudican" (77). En 1804 se trató de corregir la situación separando a Rico y Ortiz de Taranco de sus cargos, pero las cosas no mejoraron. La factoría de Arequipa y la casa de Buenos Aires tampoco iban por mejor camino. Esta última debió soportar todavía el acoso que produjo la invasión inglesa en 1806.

Las factorías de México y Centroamérica no escaparon a estos problemas. Hubo años en que los negocios se vieron coronados por el éxito, pero no pudieron sustraerse a las dificultades que ocasionaban las frecuentes guerras al tráfico por el Atlántico. En otras ocasiones tuvieron que devolver mercaderías "por invendibles", como consta en varios expedientes (78). Los excesos del crédito también conspiraron contra la Compañía. En 1808 uno de sus directores en Madrid, don Victoriano Hernández Santa Cruz, decidió enviar a su hijo a Guatemala a liquidar sus intereses, "que por las actuales circunstancias no se sabe su

(75) Informe relativo a la situación de la casa de los Cinco Gremios elaborado por don José Canga Argüelles. Madrid, 20 julio 1834. AGI, Indiferente General, leg. 1623.

(76) Carta de Manuel Rodríguez y Valle al Secretario de Estado y del Despacho Universal de Real Hacienda. Cádiz, 2 enero 1812. AGI, Indiferente General, leg. 1623.

(77) Carta de los directores de los Cinco Gremios a los comisionados Rico y Taranco, 8 marzo 1803. Citada en Compendio o extracto de las tropelías, Lima, 1811. Sobre lo mismo se quejaba en 1804 el Conde de Villar de Fuentes, nombrado interventor de la factoría de Lima, diciendo "que no ha podido conseguir otra cosa que ser el juguete de la travesura y dispendio de los dos" (se refería a Rico y Taranco), Carta de Manuel Rodríguez y Valle [76].

(78) AGI, Indiferente General, leg. 1623. 
verdadero valor" (79). En esas condiciones, era difícil llegar a un arreglo justo y conveniente para la empresa.

En España tampoco estaban en mejor pie. De partida, el fuerte crecimiento de la Compañía no estuvo acompañado de reformas que mejoraran su administración. Se sucedieron así una serie de fraudes, malas inversiones y las disputas propias de un grupo de intereses tan diversos, que terminaron por debilitarla (80). En segundo lugar, habría que considerar que la situación de España distaba mucho de ser favorable para una institución de tal magnitud y complejidad. Las guerras del XVIII le ocasionaron serios problemas y la invasión napoléonica fue para ellos un verdadero tiro de gracia. Una vez expulsado el invasor, apelaron de nuevo a la protección de la Corona, pero Fernando VII les volvió la espalda. Para entonces habían perdido la solidez y el prestigio de los años anteriores. Por último, no cabe duda de que empezaron a ser desplazados por nuevos grupos económicos, especialmente por aquellos que se desarrollaron en la periferia, cuyas actividades se confundieron, por algún tiempo, con las que ellos mismos habían tomado bajo su control al promediar el siglo XVIII. Cumplido su ciclo histórico, debieron ceder paso a sectores más dinámicos, en los cuales el propio gobierno empezaba a confiar.

A partir de la invasión napoleónica y la Independencia de América, la extinción de los Gremios abarcó un período de casi 20 años. Aunque lucharon afanosamente por recuperar la fuerza que habían tenido, en 1823 muchos de sus asociados estaban en quiebra. Hacia ese año quedaba ya muy poco de lo que había sido la antigua Corporación. En 1833 la dirección creía que aún se podía salvar la situación. En 1842 se insistía en que los numerosos créditos pendientes que aún quedaban en América y algunas propiedades de valor dejadas en las viejas colonias, permitirían levantar de nuevo a la Compañía. Pero, el estado a que llegó en 1846 obligó a la Junta General a transformar a la antiguamente poderosa Compañía General en la Compañía Fabril de los

(79) Informe de don Victoriano Hernández. Santa Cruz. Madrid, 30 mayo 1808. AGI, Indiferente General, leg. 1623.

(80) En un informe firmado por una persona allegada a los Gremios y que sólo firmó con su apellido (Calderón), se vaticinó, hacia 1780, el fracaso de la Compañía por su incapacidad para agilizar su dirección y controlar mejor sus actividades. Parece haber sido este uno de sus problemas más graves, que no pudo superar. Véase, Observaciones sobre los Cinco Gremios Mayores de Madrid (Calderon), sin fecha, presumiblemente redactadas en $1780, \mathrm{MB}$, manuscrito $\mathrm{Eg}$. 513. 
Cinco Gremios, dedicada exclusivamente a la fabricación de tejidos.

Típicos representantes de la burguesía mercantil, conservadora, tradicional y poco dispuesta a modernizarse, los Cinco Gremios no pudieron competir, como insinúa Pere Molas, con la burguesía industrial que irrumpe en el XIX (81). De este modo se extinguió una empresa surgida en la endémica España del XVII y que cobrara singular pujanza en el XVIII, como último resabio del Antiguo Regimen español.

(81) Mol.AS [4], págs. 71 y siguientes, y 81-83. 